\title{
The Ideal of Emancipation in the Name of Life Female characters in Ismail Kadare's works published during the communism period
}

\author{
Ylli Sula \\ University of Tirana, Tirana, Albania
}

\begin{abstract}
The purpose of this paper is to analyze and bring to light the symbolism concepts and messages that the female characters of Kadare contain and convey sometimes directly and resoundingly and sometimes in a more discreet, implied, or even hidden way. Because of the censorship and pressure exerted by the communist regime guided by Marxist-Leninist ideology, communist morality, and the ideal of the "new man" and the "new woman", the works of Kadare published during that period abound with such symbolism, concepts, and messages. His ideal of woman emancipation animated by love and dignity, by its aspiration for freedom, for the full blossoming of her sexuality and intimacy, not only refuses the communist models of the "new woman" by going far beyond them but takes shape and presents itself as their perfect anti-model which springs to life, moves and evolves in a parallel world and imaginary modernity.
\end{abstract}

Keywords: Kadare, novels, female characters, dictatorship period, censorship, emancipation, Albanian literature. 


\section{Introduction}

It is an obvious fact that communism ushered in a new era of modernity for the Albanian woman. Its main merits are to have dealt a decisive blow to the enslavement of women and to the mentality which governed it, to have posed openly and forcefully the problem of equality between men and women in all areas of life, and for having taken some important first steps on the path to her emancipation. But, this emancipation was above all inspired by the concern for fidelity to the Marxist-Leninist ideology and its ideal of the creation of the "new man" and the construction of the "new life". The great paradox and the greatest mystification of communism were to claim to liberate man from exploitation while replacing it with the consented sacrifice. What in reality was privation was called abnegation *. The "self-giving" was only the internalization of the constraint pushed to its perfection. The "new life" being always for tomorrow, the first sacrifice to be made was that of the present: an eternal offering that every "Cause-God" requires. Stifled by the feeling of guilty happiness, the present withered and withered away. Every man was thus supposed to become the executioner of himself. His only enjoyment was to have the "feeling of accomplished duty".

It was the same in the field of the emancipation of women. Communism endowed it with the right to say "I exist" and "I desire". But, at the same time, all this had to be put at the service of the "cause of the revolution, of the fatherland, of the people, and the Party", while waiting for the paradise of the "bright tomorrows" to come. The "I desire" thus sacrificed and conditioned ended up being almost completely repressed. And everything that was repressed in "I desire" had to let off steam in "I must". The fight for life was thus abstracted from the fight to live this life in the present.

"But normal life is the worst enemy of the totalitarian state", $\left(^{1}\right)$, writes Kadare.

This is how he describes the clash between totalitarianism and life:

"The totalitarian state strives to create a "new life", "a new man". But life makes resistance, it slowly withdraws, tries to counterattack. Exhausting itself in this battle, it also experiences the dictatorship. The dictatorship has police, army, Party militants, newspapers, TV, classics of Marxism-Leninism. Life has an infinite army, unorganized, anonymous, dominated by the

\footnotetext{
* in Albanian, the word vetëmohim which indicates at the same time the abnegation and the giving of oneself mean: selfdenial. The laudatory connotation that this word took on leads us to reflect on the paradox engendered by any "Cause" from the moment it demands that we sacrifice ourselves for it. This paradox becomes even greater and involves even more horrors and absurdities that the Cause is in itself beautiful and noble and that it promises to bring the fulfillment of man.

1) Printemps albanais, Fayard, Paris, 1991, p. 232
} 
following ranks and badges: young girls who, despite all their poverty, strive to dress well and do their hair in fashion; men and women who go to dinner (dinner with each other, as everywhere in the rest of the world); individuals who speak a normal language, free from Marxist monstrosities; invincible women who, against and against all Party pressures, calls for class struggle and vigilance against the enemy, etc., fall in love and make love; boys who get together for a drink or just to be "bored humanly"; old men who make their sign of the cross, old women who feel pity, people who whisper, as in New York or as in Zurich: great gods, how quickly winter has arrived!

This troop which does not appear in any analysis, any chronicle, any police file, this imaginary army, it is precisely this which will annihilate the dictatorship. Because it is the deep well where the models of life have been deposited" $\left(^{2}\right)$

We can see that the woman occupies a place of first importance in this "army of the life". We can, at the same time, note some of the main aspects which characterize, in Kadaré, what we have called "modernity", such as concern for oneself, dignity, the right to an intimate life and to love as a passion which, better than any other, has preserved its dose of freedom, etc.

It is undoubtedly her refusal of the "old world" which is at the starting point of the emancipation of the Albanian woman, but "the refusal which does not emanate from the will to live is only a new refusal of life" $\left(^{3}\right)$, writes Raoul Vaneigem. Emancipation becomes an empty word if it is not put at the service of life. This is the essential difference between the communist reality and the Kadarean vision of emancipation, the difference between emancipation sacrificed to an ideology and emancipation conceived in the name of life.

\section{Refuting by Going Beyond}

Kadare makes the primacy granted to life a battle horse against the communist models of the "new man", and in particular those of the "new woman". His female characters, which appear in works dedicated to the communist era, are the very negation of these models. This negation is much more the result of going beyond these models, than of direct opposition or rejection. This going beyond is the logical outcome of any refusal which is not sufficient in itself, of any

\footnotetext{
2) Printemps albanais, op. cit. , p. 238-239

3) RAOUL VANEIGEM, Le livre des plaisirs, Ancre, 1979, p. 111
} 
refusal which cannot be reduced to an exorcism in which the inability to LIVE is consoled, but which is inscribed in the name of LIFE.

In Kadaré's eyes, direct and violent opposition, hatred, the desire for revenge, the vengeance, and the settling of scores are not worth overtaking, which, in turn, only exists if it affirms the primacy of life. Analyzing the ways of approaching what he calls "the last dialogue with the dictatorship", he writes:

"We can say to the dictatorship:" Witch, you are going to die alone, while we are going to live! "This will not rule out the tragedy, but on the contrary will precipitate it. We can also say:" Enough of the word death! We have a flag, that of life. "That would be much more reasonable. But, to get there, the people - they who, without knowing it themselves, often hold the keys to history, thanks to these infinite means which belong only to it - must lead him to understand that it is not inevitable that a dictatorship knows only one epilogue: its overthrow in violence. It is not its overthrow which most surely leads to the death of a dictatorship. Its final death occurs after its roots and the sources which feed it have been cut. The word "overthrow" must therefore be replaced by the word "drying out". A dried-out dictatorship is more dead than an overthrown dictatorship. " ( $\left.{ }^{4}\right)$

And nothing can make the image of dictatorship more "dry" than its confrontation with life, its joys, its pleasures, and its infinite wealth. As far as our subject is concerned, this going beyond is deployed in a form where we see the Kadarean ideal of the emancipation of women being superimposed on the feminine reality under communism.

\section{Between Reality and Aspiration}

For most of those who lived in Albania under communism, the image of the woman as she appears especially in the novels The Great Winter, The Concert, The Monster and in the stories Moonlight, The Weeding Procession is Frozen in Ice and Let something of Ana live, is as much, and sometimes more, unreal than real.

Indeed, this image is often that of a half-real, half-dreamed woman. We are tempted to explain such a phenomenon in Kadaré by the particularly important presence in his life and in his inner world of what he calls his "second homeland" and which is none other than the

4) Printemps albanais, op. cit. , p. 223-224 
imaginary universe of literature, where he has taken refuge, as he confides, whenever he has found himself uncomfortable.

" It was one of those individual homelands, he explains, that each is forged according to its temperament, and that is why it differs from one subject to another. For a long time, as dreams often are, my second homeland was much more powerful, colorful and fascinating than my proper homeland." ( $\left.{ }^{5}\right)$

The "power", the "colors", the "fascination" of this second homeland could not pass without leaving traces and without being reflected in the creation of Kadaré; hence, as for the subject which concerns us, this truth mixed with poetry, poetry all the more present since it is a question of a feminine reality. (Besides, Kadaré does not conceive that one can ask the question "What is the most beautiful poem?", without adding immediately after "The most beautiful woman?") $\left({ }^{6}\right)$, although he is aware that "in literature, no one can ever say with precision which woman has created the pearl" $\left({ }^{7}\right)$; which lead to this enrichment, this prolongation of life by the ideal and the aspiration.

This enrichment is not limited to making more "powerful", more "colorful", more "fascinating" the imaginary universe of Kadaré, but it constitutes at the same time a claim for an inviolable part of individual freedom and, above all, an appeal to the primacy of life. In this interweaving of the real and the imaginary, we can also distinguish an ideal of emancipation which, by the essential part that it grants to the individual, to the respect and dignity that this one owes to himself, offers a seductive example from which Albanian women under communism could get inspiration.

Kadare is aware of the gap that exists between his fiction universe, marked by the desire of going beyond and by his aspirations, and the reality of the majority of people during the times of communism. This discrepancy, which he reveals to us, as we can see in this dialogue which takes place between two young soldiers, in The Great winter; the first comes from the province, and the second from the capital:

"- Is it true that in Tirana young girls go alone to the bars? - asked a conscript.

- How, alone?

5) Le Poids de la croix, Fayard, Paris, 1991, p. 283

6) Ftesë në Studio, Naim Frashëri, Tiranë, 1990, p. 222

7) Ftesë në Studio, op. cit., p. 108-109 
- Without being accompanied.

Ben's eyes softened.

- Of course, yes, he replied.

- Nice, said the young soldier, biting his lower lip. $\left({ }^{8}\right)$

It is precisely among these women of the capital that Kadaré chooses his characters.

\section{City Women Characters and Emancipation}

All the female characters of Kadaré who play a certain role in the works dealing with the era of communism are therefore city dwellers: intellectuals or students. Such a choice seems very significant to us and deserves our attention to consider it more closely.

Indeed, several innuendos can be drawn from it. We can, first of all, underline Kadaré's refusal to incarnate in his works the main models of the "new woman", such as the peasantcooperativist, the woman in the factory, the woman promoted to the institutions of the Party and of the power, the city-dweller who goes to live in the countryside, etc.

Then, such a reduction, in a country where more than $60 \%$ of the population lives in the countryside, swears with one of the essential standards of "socialist realism": "the typical in literature", which was based on the fetishized formula of Engels that one had to create "typical characters who evolve under typical circumstances". This is what has earned Kadaré repeated criticism of "living apart from the life and concerns of the broad masses of the people" and his reputation as an elitist writer.

Finally, the choice of his female characters among intellectuals and students prevents him from being obliged to praise the "titanic struggle of the Party for the liberation of women" and "the relentless march of Albanian women in the path of emancipation enlightened by the teachings of the Party and comrade Enver ". He, therefore, refuses to represent the woman as a baby that one takes by the hand to teach her to walk in this "new world" for her.

From the outset, his female characters appear to have reached a very high level of emancipation. From this moment, two scenarios arise. Or they take advantage of this emancipation to take the initiative to give their life the meaning that suits them and to live it intensely, as is the case with Ana and Zana in The Great Winter, or Silva and Linda in The Concert, etc.; or else, they see themselves obliged to fight to defend their emancipation and

8) Dimri i Madh, Naim Frashëri, Tiranë, 1983, p. 606 
the dignity with which it endows them, as is the case with Marianne in Moonlight. In the latter case, given that these women are ahead of their time, they push the society to emancipate itself, forcing it to accept their emancipation.

Among these city dwellers, Ana Krasniqi is undoubtedly a figurehead. As we discover it in Le grand hiver, and, as she is described to us after her death, in The Concert, she seems to us to embody better than any other female character some essential features of the Kadarean ideal of the emancipation of women. But, at the same time, and perhaps above all, she represents the image par excellence of an "anti-" new woman ".

We have noted the main features that constitute this opposition:

\subsection{Socio-political engagement:}

"The socialist attitude towards work and life, towards society and the State, towards the people and the Fatherland has now become the fundamental criterion for judging the men of our new society"( $\left({ }^{9}\right)$, wrote Enver Hoxha.

"They (Albanian women) see work not only as a means of earning a living and consolidating their economic independence but also as a necessity for them to make their contribution to the construction and defense of socialism in Albania. $\left({ }^{10}\right)$, proclaimed an official publication.

We do not find anything in Ana that looks like this. No political engagement on his part. Not once she speaks of socialism, the Party, etc. She seems to live detached from these realities. When, during a conversation, people around her allude to the blockade that the Soviets are preparing against Albania, the only thought she can think of is:

"Just as long as there is no obligation to save money "; "Really, there's nothing I hate more than having to save."; "Savings, wow, what a horrible word!" $\left.{ }^{11}\right)$. And all this at a time when, in the four corners of the country, the slogan was written: "Let's save everywhere and in everything" and as Enver Hoxha proclaimed:

"We will eat grass, but never give up on our principles."

However, ideological principles do not interest Ana. What matters to her is life and love. His life is an expanded present, delivered to the pleasure of subjectivity, immersed in dreams, embellished with playfulness, and above all swimming in love:

9) ENVER HOXHA, Le socialisme en Albanie, Union Générale des éditeurs, Paris, 1974, p. 23

10) KSANTHIPI BEGEJA, La famille en RPS d'Albanie, Tirana, éditions "8 Nëntori", 1984, p. 33

11) Dimri i Madh, op. cit. , p. 457-458 
"She had done a lot of things in her life, just for fun, in a reality that was like glass ..." ( $\left.{ }^{12}\right)$

"She remained a long time in that ethereal, transparent state, imbued only with love, out of reality." (13)

"... for Ana the aspect of men was irrelevant, just as she didn't care whether or not she was having an affair with the man she loved. For Ana, the important thing was that she loved, the rest was secondary, even boring, and she tried to shy away from it. So it happened that she fell in love with men who had never realized it. Sure of her power to lead her love to its fulfillment, she sometimes chose to be satisfied with its sketch. Sometimes she did not know how to give a concrete image to her love, she was simply inhabited by love. Love of someone who may not have existed in this world, or who had lived there before. " $\left({ }^{14}\right)$

\subsection{Perception of motherhood:}

"Thanks to the right demographic policy of our socialist state, and to the educational work carried out to maintain the tradition of Albanian women giving birth and raising as many children as possible, good results have been recorded in the increase in the number of births ... $"\left({ }^{15}\right)$.

The fact is that, following such a birth rate policy, the population of Albania has more than tripled in 50 years.

"In Albania, mothers who have given birth and educated eight or more children in the spirit of socialist patriotism and whose lastborn has reached the age of one year, are awarded the title of " Mother heroine " As for those who have given birth and educated 7, 6 or 4 to 5 children, they receive the order "Glory to the mothers" of 1st, 2nd or 3rd class. " $\left({ }^{16}\right)$

Now here's what Ana thinks:

She... passed her hands on her hips. The thought that the time had come to have a child sluggishly crossed her mind. A child, on her face, a nonchalant smile slipped. A small being

\footnotetext{
12) Ibid. , p. 726

13) Ibid. , p. 725

14) Ibid. , p. 723

15) KSANTHIPI BEGEJA, La famille en RPS d'Albanie, op. cit. , p. 38

16) Ibid, p. 39
} 
crawling, wailing, constantly wiggling her handcuffs and paws, would deteriorate that perfect body, transform its lines, upset dietary regimes ... Later, later, she thought. " $\left({ }^{17}\right)$

\subsection{The concept of divorce:}

"Based on the Marxist-Leninist conception of marriage, our family law provides for the dissolution of marriage, if divorce is requested by one of the spouses, and the court is convinced of the serious deterioration of the marital relationship and of the impossibility for the spouses to continue to live together. To judge the state of the relations between the spouses, the Albanian law is not based only on the only subjective considerations of the spouses, because this could lead to manifestations of liberalism, to the deterioration of marital relations and would harm the interests of the family ... Contrary to the laws of capitalist and revisionist countries, our socialist legislation does not allow the dissolution of marriage outside the courts, nor does it take into account the only one consent to the divorce of the spouses, if they do not advance the causes for which they are asking for the divorce. " $\left({ }^{18}\right)$

Ana's divorce, meanwhile, seems to ignore these laws. Kadaré first tells us about "each other's endless conjectures on the reasons for their separation" $\left({ }^{19}\right)$. "Then (of) the unexpected turn taken by the case when it was established that Ana's decision was not linked to Skënder Bermema (with whom she had had an enigmatic relationship), but to her relationship with Besnik Struga and their sudden intention to marry as soon as possible " $\left({ }^{20}\right)$. Ana herself announces her divorce to her sister in these terms:

"Silva, I'm going to divorce Frederic ... She remembered very well the moment when she heard those words fall from Ana's mouth. It was a cold leaden day, just like this one, which granted no mercy to the reckless who dared to transgress the right measure. It is on a day as frozen as this one that Ana, the face a little paler than usual, had repeated these words: I I'm going to divorce Frederic ... Silva had not yet recovered from her amazement when Ana had uttered the following sentence, even more astonishing: I am going to marry another. " $\left({ }^{21}\right)$

Kadaré does not at any time and in no way attempt to demonstrate "the serious deterioration of marital relations" or to "put forward valid causes" to justify the request for divorce. On the

17) Dimri i Madh, op. cit. , p. 722

18) KSANTHIPI BEGEJA, op. cit. , p. 58

19) Koncert në fund të stinës, Onufri, Tiranë, 2008, p. 14

20) Ibid., p. 15

21) Ibid., p. 144 
contrary, he continually insists on the element of surprise provoked by Ana's decision, on the promptness and the suddenness of this decision. What matters is that Ana loves Besnik and wants to marry him.

Kadaré, who most of the time merely tells, describes, in the short show, with restraint and a lot of distance, in Ana's case do not hide his sympathy for this character. Sometimes he even sided with Ana openly. This can be seen in the description of her divorce:

"... the court, according to some, had almost turned to the literary jury, the judge having fought for days, at the request of the husband whose ridicule had only redoubled, to decrypt certain pages of the work of Skënder Bermema that, in his obstinacy, Frederik claimed to be dedicated to Ana. " (22)

In another passage, later in the text, he qualifies Frederik's attitude as "petty", underlining at the same time the "very dignified behavior of Ana throughout the trial" $\left({ }^{23}\right)$. "Then the dead calm after this storm that Ana, with her gift of making everything around her luminous and ethereal, soon turned into a simple spring blast." $\left.{ }^{24}\right)$

Everything about this character is out of the ordinary. Until the mourning that her mother wears for her:

"Unlike the usual bereavements, there was in her mourning something greyish that seemed to make it easily bearable, because it spread evenly over all the days. Sometimes, thinking of his mother's behavior, Silva said to himself that it was the kind of mourning that suited Ana." $\left({ }^{25}\right)$ Ana's death comes very early. Kadaré confines himself to announcing it in The Concert, without describing it further. He suggests that it occurred in the period between The Concert and The Great Winter. But her image is still present in the minds of her old friends. Everyone has boundless admiration for her, which prompts one of the characters in the novel to exclaim:

"Who was this dead woman who left behind her only peace and light?" $\left({ }^{26}\right)$

Ana's death gives rise to several assumptions:

\footnotetext{
22) Koncert në fund të stinës, Op. cit. , p. 14-15

23) Ibid., p. 145

24) Ibid.

25) Ibid., p. 12

26) Ibid., p. 502
} 
We can think that, in the face of the daily reality of most Albanian women, Ana's story must remain what it was in several aspects: a dream too good to be true. Its message was to say that we can dream, that we must dream. The fact that someone had dared to dream and talk about his dream, now made the content of that dream conceivable and accessible.

We can also suppose that, by the death of Ana, who seals forever the mystery with which Kadaré has surrounded her, he meant to say to the totalitarian system for which there should be no secret: "You will never succeed to know everything.".

We could also think of the attraction that death, in general, exerts on Kadaré, who sees in it "the ideal companion of life", "a companion with whom one has flirted a whole life before marrying her" $\left({ }^{27}\right)$. In Ana's case, we could repeat what Kadaré, with a certain fatalism, makes Silva say about Besnik: "perhaps he is like this because he has exhausted all the dose of happiness that a human being may be thirsty in the course of his life " $\left({ }^{28}\right)$. In her turn, Ana, after her youth, "these years filled with exhilaration" $\left({ }^{29}\right)$, after having "done a lot of things in his life, just for fun" $\left({ }^{30}\right)$, while being permanently "imbibed only with love"( $\left.{ }^{31}\right)$, after "the romance between her and Besnik" and their "perfect happiness" $\left({ }^{\mathbf{3 2}}\right)$, she also seems to have "exhausted the dose of happiness" that was allotted to her.

\section{Dignified Women}

Dignity seems to be the quality that Kadaré values most in a woman. It is present in all female characters who have her sympathy, appearing as the most representative quality of an emancipated woman. There can be no real emancipation if it does not involve dignity.

What makes dignity so essential is first of all the fact that it is presented as the sum of several other qualities. It is then, the fundamental place that it occupies in the way in which an individual conceives and establishes his relations with the others, but also in the attitude of this one towards oneself. When a woman treats herself with dignity, it means that empowerment has become part of her personality.

27) ERIC FAYE, Ismail Kadaré, Prométhée porte-feu, José Corti, Paris, 1991, p. 116

28) Koncert në fund të stinës, op. cit., p. 144

29) Ibid., p. 14

30) Dimri i Madh, op. cit. , p. 726

31) Ibid., p. 725

32) Koncert në fund të stinës, op. cit. , p. 143 
To better bring out and highlight it, Kadaré will ensure that all these characters find themselves at one time or another in a situation in which they will have to show dignity.

We have already mentioned "Ana's very dignified behavior throughout the trial", which Kadaré points out without hiding his esteem. Here is now a dialogue between Gent and Lena in The Monster:

"Helen of Troy ..." Gent said as if addressing himself. Do kids keep calling you by that name?

- Sometimes. But less than before. You have to believe that they don't like me so much anymore.

- Do you think they honor you by calling you that?

- I will not have the false modesty to say the opposite.

- I don't think so.

- I thank you! However, ...

- Basically, even if she was at the origin of a formidable history, Helen of Troy was herself only a mediocre woman.

- Why, then?

- How why? Gent exclaimed. Would you agree, for example, after our affair, to hunker down and go back to live with your ex-fiancé? (It was an arranged engagement)

- Never! Lena said. That, never!

- Well that's exactly what she did. After this terrible conflict, she recovered with her exhusband and spent quiet days by his side, in their palace where they received news from time to time from the rest of the world.

She remembered Gent's notes entitled: One Year After the Fall of Troy. At the palace of Ménélas. Spring.

- You see: you say "never". It shows that you are superior to her. " $\left({ }^{33}\right)$

* thashetheme, in Albanian: gossip, slander raised to the rank of a general rumor. The communist regime adopted a very ambiguous attitude towards this phenomenon: on one hand it condemned it because it feared it, given that it is a mechanism that is difficult to control and which could turn against it; on the other hand, it tried to exploit it by pushing people into general denunciation, to sow 
This "superiority" cannot be attributed to any quality other than dignity.

It is in Moonlight Night (Clair de Lune) that we find the most beautiful homage written by Kadaré on female dignity. This novel holds a special place in Kadaré's work. More than anywhere else in the entirety of a work, going beyond is mixed with revolt. Kadare indulges in a fierce mockery against the taboo of virginity and all the absurdities that it entails. $\mathrm{He}$ furiously attacks the infernal mechanism of the thashetheme ${ }^{*}$, denouncing at the same time the interference of the totalitarian state in the private lives of people. In a society that prides itself on being socialist, therefore fundamentally healthy and united, Kadaré brings to life characters who, far from extolling the "triumph of the pure qualities and values of the new man", rather make one think at those wolves Hobbes spoke of.

To these taboos and these cogs, as grotesque and absurd as they are ruthless and murderous, Kadaré opposes the dignity of Marianne, the heroine of this novel. Her story is nothing other than the story of a sanctified female dignity.

Marianne, a young girl, very beautiful, laboratory manager in a company in the capital, is accused of having made advances to Gazmend (engineer in the company) when he was about to get engaged with Nora (employee) and, therefore, to have wanted to destroy their marital happiness. Now, this was the truth: "After an evening that had gone on very late, Gazmend, who lived in the same neighborhood as her, had accompanied her home. It was a soft moonlight night, Marianne felt the soul spongy as if engorged with all this lunar moisture. " $\left({ }^{34}\right)$

Quite spontaneously, she pronounced a few lines of poetry on love, immediately feeling "sounding within her the alarm ring which triggered there each time she put someone in a situation to misinterpret some of her words or gestures. " $\left({ }^{35}\right)$. "To be completely sincere, on that sweet moonlit evening, she had felt a need for tenderness, perhaps she had even wanted to be hugged, but those impulses hadn't nothing to do with Gazmend as such, it was

distrust among them, to make each one a volunteer policeman towards the others and thus prevent any form of collaboration and organization for the opposition.

33) Le Monstre, Fayard, Paris, 1991, p. 206

34) Clair de Lune, Fayard, Paris, 1993, p. 22

35) Ibid., p. 24 
something vague, undefined, as in the lyrics of the song: it was not you or I who loved, but love ..." $\left({ }^{36}\right)$.

Nora, under her air of an effaced and unpretentious girl, hides a concealed ambitious person, animated by devouring greed for the pleasures of life. Driven by a troubled feeling of revenge (someone had to be responsible and had to pay for the mediocre life she had led until then!), Jealous of everything about Marianne, "of her looks and her class, of her laughter, of her approach, but also (surprisingly) of the sadness which seemed to invade him the day after her break with Philippe (another engineer), of this mystery " $\left({ }^{37}\right)$ surrounding this break, she clings to this story, even if she knows that the truth is quite different, in order to taste "what in secret she had until then so desired: to make an impression" $\left({ }^{38}\right)$.

"Eager to enrich his life with something that neither the furniture dealers, nor the lace makers, nor all the upholsterers in Tirana could provide for her" $\left.{ }^{39}\right)$, she will strive to convert this story into a "gold mine for herself, in a firedamp pit for Marianne ".. $\left({ }^{40}\right)$

The rumor thus fueled on several sides begins to take shape. "The torture apparatus" $\left({ }^{\mathbf{4}}\right)$ was turned on.

In competition with human pettiness and wickedness, the totalitarian state, in turn, cannot be indifferent to such a story. According to the words of the deputy director of the company, Marianne, by her gesture, went against the "concern of the Party for the happiness of the people" and its "educational work to be carried out against bourgeois and revisionist influences in the field of what was called sexual freedom, which led to the disintegration of the family " $\left({ }^{42}\right)$.

The affair must therefore be brought to light by the Collective, under the direction of the Party organization. The meetings follow one another indefinitely, as absurd as they are torturing. Kadare never describes the members of the collective of this company at work. It is also not known what this company produces. It seems it exists only to make thashetheme. The

\footnotetext{
36) Ibid., p. $27-28$

37) Ibid., p. 54

38) Ibid., p. 52

39) Ibid., p. 55

40) Ibid., p. 56

41) Clair de Lune, op. cit., p. 122

42) Ibid., p. 76
} 
endless meetings and the absurd, inquisitive and ostracised atmosphere that reigns there take on the appearance of a Kafkaesque trial. Marianne will be presented as a "flighty woman" who goes from one man to another and "ignites the rivalry between them" $\left({ }^{43}\right)$, as the "symbol of depravity, born to bring misfortune to others" $\left({ }^{44}\right)$. She will be described as a "vamp", a "femme fatale", or even a "murderous beauty" $\left({ }^{45}\right)$. But Marianne is ... a virgin. One of her close friends, wanting to end the nightmare, finally shouts this truth in front of everyone. Someone will then go so far as to ask him to provide a medical certificate of virginity to prove it. All those who supported Marianne think that "to consent to the request meant to submit to baseness and affront, to reject it was to perpetuate Marianne's stain" $\left.{ }^{46}\right)$. They resign themselves and succeed in convincing her to submit to such a request, to go to a clinic, from where she leaves with her certificate in hand:

"Without slowing down, she examined the sheet of paper. Among the scribbles, she could only make out the word virginis. A drop of rain (it was mid-autumn) fell on it and lengthened the middle I, but the fear that more drops might erase the words of the attestation only crossed his mind. Instead of stuffing the paper in her bag, she continued to wave it as people do for a bill they intend to pay on time. Like a tear, another drop added a jamb to a letter. How strange, she thought: she held her honor in her hands ... She imagined the laboratory room gradually filling up, the welcome they would give her, the uniform buzz before the debates began. Then, like the flashes preceding an upturn, the triumphant words of her sympathizers, and the heads of her adversaries bent as if to implore forgiveness. And this miracle, this reversal of situation would be the work of this thin sheet, or more exactly of this word borrowed from a dead language to restore its honor ... But, ah! a third drop had again added as a tail to the finals. Now that the droplets were intensifying, instead of protecting her paper, she regarded it in astonishment, as a bizarre object, then, reaching out with her other hand, she folded it in four and tore it. She held the pieces in her fist for a few moments, until her eyes fell on the ridge that the rain had formed along the curb. She threw the torn slip into it and, without looking away to see if the current was carrying the pieces of paper towards some sewer grate, she continued on her way home. " $\left({ }^{47}\right)$

\footnotetext{
43) Ibid., p. 72

44) Ibid., p. 49

45) Ibid.

46) Ibid., p. 99

47) Clair de lune, op. cit. , p. 120-121
} 
Human dignity prevailed. But Kadaré goes even further. This is what he makes the characternarrator say:

"After her gesture, all of our reasoning, before and after the meeting, which had seemed so logical to us to defend her, seemed to us meaningless. She had shown how much she was ahead of us, and, with a gesture, she had freed herself and at the same time delivered us from this apparatus of torture that suffocated us all.

It was like an announcement made through a tear in the sky that left us all in shock. It was all the more incredible since Marianne had never maintained any kind of relationship with the powers of the beyond from which such a sentence could fall. A form of omnipotence still emanated from her message, and we were to understand later that in this circumstance Marianne had given the first sign of her divinity. " $\left({ }^{\mathbf{4 8}}\right)$

We are invited to become witnesses to the sanctification of dignity. The reader is greatly surprised by the intervention of this new dimension, so unexpected in a setting where the issue seemed to be limited rather to human prosaism, despite the scope of the values that we saw defending there and the strong impression produced by their fight against evil. But, again, Kadaré tells us, this is only a sign. The expectation of the reader is thus invited to change level, too. It is not a very easy thing, because this new level surely exceeds most of us. So all we have to do is fix the "tear in the sky", from which this first sign sprang and wait for the consecration. After a long moment of suspense, which endeavors to confuse us further, this consecration will be marked by the worst sacrilege that has ever been committed against socialist morality, in a literary work from the communist period:

"... she resumed her work after three days as if nothing had happened. And this as if nothing had happened appeared overnight like a message, a warning in the eyes and expressions of each. "A tacit agreement surrounded her like a wall of crystal that no one dared to crack or splash.

Some time passed thus, until one fine day it appeared that this idyllic calm had ended. This time, it was Marianne herself who broke the crystal wall. She began to thicken ... On her cheeks and her lips, there was initially a sweet swelling which then gained the rest of her body. She was pregnant. No engagement or, at least to our knowledge, the slightest sentimental affair in her life. We were all the more amazed that she did not try in the least to conceal her condition ... No one dared ask her for explanations, and she considered it

48) Clair de lune, op. cit. , p. 122 
superfluous to provide any ... $\quad$ A stranger, it was said, had once asked to see her at the concierge, but their conversation had turned into a dialogue between the deaf: I'm sorry, she said, but I don't know you. He had insisted: Why are you trying to avoid me? I didn't do anything wrong to you, it was you who invited me that evening ... She then replied in a calm voice: You must have been dreaming. Then turning her back to him, she had slowly walked away ... In her gaze, there was only the trace of a feeling that seems to have long since fallen into oblivion in our time: compassion.

Perhaps it was this brief encounter in front of the concierge's lodge that fueled the slight rumor that one evening (it was probably moonlight), she had invited a stranger to her home, or at least someone. whom she had just met, and, after giving him a few moments or days of happiness, she had kicked him out of her life for reasons only she knew. Maybe she was trying to persuade herself now, or did she believe that she was only dreaming about this episode? " $\left({ }^{\mathbf{4 9}}\right)$

Marianne will give birth to a "beautiful as day" baby $\left({ }^{50}\right)$. Friends who have gone to visit her will see "except her parents, neither husband nor fiancé, no one else" $\left({ }^{\mathbf{5 1}}\right)$. The evocation could not be clearer. But it is perhaps because of this that we hesitate to name it, for fear of being completely wrong and because something deep inside us has difficulty believing that such an event can still happen today and even less in communist Albania. And yet it happened, before our eyes:

"From her immaculate bed, she looked at us in turn, serene, smiling, the new Virgin Mary who had come to earth when we least expected her." ${ }^{(52}$ )

The consecration has taken place. It is neither more nor less than the reinvention of holiness itself. To the question of whether there can be holiness, today, in a world that seems so prosaic, so material, so pragmatic, and often even Machiavellian and treacherous, Kadaré answers yes, on condition of rediscovering pure, eternal, and universal values, such as dignity and compassion. And it is possible. Marianne * succeeded and during communism. The

\footnotetext{
49) Clair de lune, op. cit. , p. 129-132

50) Ibid., p. 132

* Maria, in Albanian Mary.

51) Ibid., p. 132

52) Ibid., p. 133
} 
values it embodies also resemble those rare diamonds that are formed "under infernal pressure".

\section{Women in four dimensions}

"She had done a lot of things in her life, just for fun, in a reality that was like glass and had a fourth dimension, its mirror. " $\left({ }^{\mathbf{5 3}}\right)$, writes Kadaré about Ana Krasniqi.

This fourth dimension, which often extends to the bathroom, we will find in almost all the female characters of Kadaré. This unavoidable presence and Kadaré's sustained insistence on emphasizing it, make this fourth dimension a constant in the Kadarean representation of women, and even of femininity.

Such a representation seems, at first glance, to align itself with all this tradition, in the first place pictorial, of the representation of the female body, inaugurated by the Quattrocento which stripped this body to show it in broad daylight, which delivered it from sin to associate it with beauty, a beauty that was sufficient in itself. In reality, this phenomenon turns out to be more complex. While taking up some traditional clichés, Kadaré nonetheless tries to demystify some of them and reinterpret them in his own way. In addition, the function and meaning of this representation are very different when moving from one character to another.

Such a complexity transforms this fourth dimension into a veritable "game of mirrors", both literally and figuratively, which, depending on the attention paid to it, may seem to amuse the reader to take the time "necessary for the events to move away from their course, for a moment $"\left({ }^{54}\right)$, or, on the contrary, can provide real aesthetic pleasures and also help to relativize the judgment that readers make on things by distrusting clichés and thinking patterns that seem to be given once and for all.

Nous avons tenté de discerner quelques "astuces" de ce "jeu" : We have tried to discern some "tricks" of this "game":

Let's start with the toilet of Daisy, the wife of the sub-prefect of $\mathrm{N}$... in Dossier H.:

Automatically, she walked to her bathroom. She stared at the cold glow of the tub for a moment, then her hands slowly reached for the hot water faucet. With languid gestures, she

53) Dimri i Madh, op. cit. , p. 726

54) ANNE-MARIE MITCHELL, Un Rhapsode Albanais : Ismail Kadaré, Le Temps parallèle, Marseille, 1990, p. 100 
began to undress. She dipped two fingers into the water to check the temperature, then, when the tub was half full, she suddenly decided to step in. More than once when her mind was haunted by thoughts of a certain nature, she immersed herself in her bath to pursue her meditations at leisure.

Thus stretched out, her eyes vague, she watched the water rise little by little and cover her body. This is how the dead are buried, she thought, but she cut the thought short, as she always did when a macabre or simply painful idea germinated in her mind. No! No! she said to herself ... She was still young, she was only thirty-two, and then wasn't she waiting for a wonderful event, the arrival of these strangers? She repeated their names to herself: Max Roth and Willy Norton. Real European names! She had done well, long time ago, to swap her first name, with its unattractive oriental sounding of Mukadez, for that of Daisy ... The hot water had now covered her whole body and she realized that she had forgotten to take her bar of soap. Never mind! She would stay that way, motionless. Maybe it would even be nicer? Yes, definitely. She had noticed that, in circumstances like this, the soap suds, along with the transparency of the water, disturbed the flight of her imagination.

With a sidelong glance, she contemplated under the surface of the water her white body, with the black triangle of her pubis, which undulated as if doubled. There was in this wavering a sort of insidious languor which made all things fuzzy and ambiguous. Although she tried not to admit it to herself, she felt that in this province overwhelmed with boredom, she was now ripe for some sentimental adventure ...

She moved with some difficulty in her bathtub, like a sleeper who rolls over in his bed. The gurgling of the water and the spectacle of her body made her imagination drift ... She stirred again and the water, after having wrinkled for a few moments, became limpid again and let the shapes of her body reappear in all their whiteness as if distressed ... A real joy awaited her, made of pleasure, of curiosity, of mystery, why did she come to alter it, by all kinds of complicated visions? The bridge cards, the wine, the warm glow of the flames in the fireplace finally tore her away from this sad picture. All these elements were emerging in front of her now, almost tangible, and would belong to her in the next few days. With sudden liveliness, she left the tub and, having put on a bathrobe, quickly went to her room to get dressed." $\left({ }^{55}\right)$

55) Le dossier H, Folio, Gallimard, 1990, p. 13-18 
It is undoubtedly the toilet of a woman, that the traditional paradigm of thinking associates with vanity and futility $\left({ }^{56}\right)$. This would not be without reason when we know the whole story of Daisy, this specter of Emma Bovary, who apparently should not "suffer and cry in twenty villages in France at the same time" $\left({ }^{57}\right)$ but also in one small provincial town in the Albania of the thirties. It is with a slightly ironic smile that Kadaré accompanies the scene.

Now let's look at the description of a queen's toilet. This is Sophie Schönburg Waldenburg, queen of Albania in The Black Year:

"I spent part of the morning in my bathroom, then I took care of my toilet for a long time much longer than usual. I opened and closed the boxes of powder, my manicure set. I tried a perfume that my aunt sent me and when, curiously, I felt the desire to immerse myself again in my bathtub, I realized that this was only the gesture of a woman who seeks to get rid of a feeling of filth. In truth, this feeling was born in me several days ago, when I learned of the arrival of the cursed letter from the partisans of Essad

... I had to listen to several horrors such as I had never heard in my life. From then on, I felt this dirty thing stuck to my skin. I tried in vain to chase it away by spending hours in my bathroom, among the crystals of the mirrors, the jewels, the brooches, the perfume, and the powder with which I unconsciously covered all this glassware more than once. I thought I would lighten the weight that was oppressing me by writing all this ... to my mother-in-law, the Princess of Holland ... Yet I could not write this letter. I couldn't concentrate or connect the sentences. Ah, the use of soap was easier! So I found myself in the bathroom, undressed, surrounded by crystals and pink marble. There I finally felt safe, in my universe... The heat of the bathtub filled with soap suds was very apt to make me recall idyllic scenes from my childhood and my virginal youth ...

Outside, intrigue, chaos, hysteria raged, as I, surprisingly serene, spent my days going from my bedroom to my bathroom and from my bathroom to my dressing table." $\left.{ }^{(58}\right)$

The novelty here is not so much in this subtle irony that touches the black humor and the grotesque, but above all in its unexpected mixture with a feeling of pity. Such a mixture is because, in Kadaré's mind, the queen's toilet is not identified only with the vanity of a body

\footnotetext{
56) CORINNE CHAPONIERE, Le mystère féminin, 1994, p. 119-122

57) FLAUBERT, quoted by Edouard MAYNIAL in the preface of Mme Bovary, Garnier Frères, 1961, p. XXIV

58) L'Année noire, Fayard, Paris, 1987, p. 65-66
} 
occupied by itself, this frequent representation of the ladies' toilette $\mathbf{( 5 9}^{\mathbf{5 9}}$. To this vanity are added the almost childish naivety of the queen (which also means innocence in some way), her weakness, her sadness, and even her suffering. Kadaré himself reveals to us, through a reflection of the queen, what is at the source of this suffering and therefore of the pity he feels:

"I understood then why, in all the tales where it is about princesses or almost, mirrors are never lacking: it is the only object with which we can share our solitude." $\left({ }^{60}\right)$

We are already far from traditional vanity, or rather, somewhere deep within it where, as we can see, we discover something very different. By noting this, Kadaré has no intention of arguing. He does not say, for example, that feminine vanity is constantly a facade that satisfies only the superficial glances, nor, either, that it is a pure masculine invention. $\left({ }^{61}\right)$, he simply suggests that, for him, it is human and can, depending on the case, be considered as a character trait, but often also as a consequence and therefore, an appearance. If it is associated above all with women, it is, Kadaré seems to answer, because she feels the weight of solitude more than man, feels the need for a presence, for support more than he does. Let us quote the thoughts that Kadaré attributes to Zana, in The Great Winter, which illustrate this fact very well:

"How does this man live without someone to whom he is attached? She thought not quite knowing why. She had only been alone for a few weeks and she was in terrible pain." $\left({ }^{\mathbf{6 2}}\right)$

On the other hand, coquetry seems to be an exclusively feminine trait for Kadaré. He takes pleasure in contemplating it and describing its gestures, seeing in it both self-care, a game of seduction, a childish side, and above all this aspect of glass vapor associated with the image of a woman "stork-dragonfly" * $\left({ }^{63}\right)$, so frequent in his descriptions. The order of importance of these aspects is interchangeable and varies from character to character. Here is Diane's slightly childish coquetry in the Broken April:

\footnotetext{
59) CORINNE CHAPONNIERE, op. cit. , p. 119-122

60) L'Année Noire, op. cit. , p. 65

61) CORINNE CHAPONNIERE, op. cit. , p. 246-247

62) Dimri i Madh, op. cit., p. 502

63) Kronikë në gur,Naim Frashëri, 1981, p. 147
} 
"They hugged, caressed each other, then she opened her bag, pulled out a small mirror, and looked to see if her faint lipstick had worn off." $\left({ }^{64}\right)$

For Silva, in The Concert, it is the coquetry of a mature woman or rather, as Kadare would say, through Gjergj, Silva's husband, a "fulfilled" woman:

"As she undressed in the bathroom, she examined herself in the mirror and felt her hips thickened a little. She stood there for a moment, thinking as if she had forgotten why she had come there. Then, from the hall, the ringing of the telephone reached her and, as if suddenly awakened, she lifted the handle of the shower.

She acted quickly, anxious at the idea that her hosts could disembark at any moment ...

Having returned to her room, she stood there for a long time, hesitating on the choice of dress to put on. But she was soon cold and, without further ado, put on a mauve dress which Gjergj liked. It still looked good on her and Silva told herself that her fear of having gained weight was not justified ... Comb in hand, she didn't think about her hairstyle for long... She chose to arrange her hair in a way Gjergj liked. Maybe it was precise because he was away, traveling, that she did her hair like this. " $\left({ }^{65}\right)$

Any girl or woman, to be truly called such, must one day or another discover coquetry. For Teuta, the young and beautiful resistant fighter of the November of a capital, this discovery is very timid and a little late because of the war and the taboos imposed by the misogynist tradition. These circumstances make it even more significant and at the same time underline the inevitability of such a discovery in the course of any female existence. "She's a girl, and she must be beautiful" $\left({ }^{66}\right)$, Javer, another resistant fighter, will say, contemplating Teuta who "combed her hair using a comb she had found the devil knows where." $\left({ }^{67}\right)$

Here is Kadaré's description:

"Teuta continued to comb her hair. She held her hair with one hand, while with the other she passed the comb very gently. Such a gesture was unknown to them, foreign, and remained distant. Out of the corner of her eyes, and indifferent, almost enigmatic light escaped which

\footnotetext{
64) Avril brisé, Fayard, Paris, 1982, p. 83

65) Koncert në fund të stinës, op. cit. , p. 10-11

66) Nëntori i një kryeqyteti "Naim Frashëri", Tiranë, 1983, p. 184

67) Nëntori i një kryeqyteti, op. cit., p. 184
} 
settled on the end of her long hair. Meanwhile, her hand continued to communicate with the wavy hair, seeking to tame and soften it. " $\left({ }^{68}\right)$

It will be the same for these mountain women of Wedding who take for the first time in their life a hot shower, the day of their arrival at the construction site of the railway:

"Like a herd of stubborn goats, we stood in front of the shower room refusing to enter. We were afraid ... High school girls came to talk to us and try to convince us, but we still refused. A youth manager of the building site then entered on her own and was the first to undress to shower. Still very hesitant, we decided to go in. Hot water was falling from everywhere from the top of the room which was plunged in the vapors. We looked surprised, without daring to step further. Finally, one after the other, we undressed. What a wonderful feeling! We had never before taken a hot shower. In our mountains, we had often seen the waterfall from the top of cataracts formed by the rocks, but we never imagined that there could be hot water cataracts and even less that they would fall on our shoulders. In a few minutes, an unexpected vivacity invaded us all. We bathed, we played, we sang. Some cried tears of joy. The water continued to flow without stopping. The soap bubbles created magnificent rainbows on our white shoulders. The time for the exit had passed, but we did not want to go out ... The water and the soap had drowned us in a kind of mad drunkenness. It was only after one and a halfhour that we decided to walk out ... " $\left({ }^{69}\right)$

Often, the discovery of coquetry happens quite naturally, especially when it comes to city dwellers, as is the case with Mira, the young student of the Great Winter. The discovery of the coquetry will coincide with the discovery of sensuality, the carnal reality of the body, and the birth of the desire to please:

"She took a deep breath, straightened up, let her legs hang out of the bed, and was about to stand up when all of a sudden she froze. With her hands on her knees, she directed her gaze to the window glass. Then she slid the epaulettes of her nightgown a bit and gazed at her shoulders. She bared them a little more and thought to herself that they were pretty. After a moment of meditation, she pulled up the hem of her shirt and observed her legs... Abruptly, she jumped to her feet in joy, and, frolicking down the hall, made for the bathroom. " $\left({ }^{70}\right)$

\footnotetext{
68) Ibid., p. 182

69) Dasma, Naim Frashëri, Tiranë, 1968, p. 81-82

70) Dimri i Madh, op. cit., p. 85
} 
It is not by accident that this discovery does not occur in front of a real mirror where the image is clear, but in front of the window glass where the image appears blurry, symbolizing the cloudy sensation that Mira is experiencing. The appearance of the image of the bathroom, which closes the scene, marks her entry into the fourth dimension.

Mary, in The hijab's caravan, goes much further. Her coquetry will appear when she has her first sexual intercourse, to then very quickly evolve into a form of accentuated narcissism.

"Half-naked, she approached the mirror and observed it by bending first one knee, then the other ... For a moment, she gazed at her smooth belly, the dark little scrub covering her pubis, then she sat down on the carpet, legs parted, contemplating her vagina.

"It's calm, she thought, as if nothing had happened."

She couldn't take her eyes off the slightly curved line between the two light pink lips. They looked like mute lips ... And to think that, a few moments before, they were like crazy, verbose, foaming ..." $\left({ }^{71}\right)$

Mary will spend long moments in front of the mirror every day. There is however no trace of irony or reproach in the description of Kadaré: on the contrary, he puts so much innocence in this character, that everything becomes natural and the character of Mary very endearing. It is the symbolic load assumed by the story and the character of Mary which explains, at the same time as her phantasmic side, this attachment that Kadaré feels towards her and that he tries to convey to the reader as well. This story allows him to commit another "sacrilege", unique in its kind, this time against Islam and its morals. Here is this "sacrilege" summarized in a few words:

At the time of the Ottoman Empire, and in the middle of the Turkish capital, Kadare places a young girl called Mary who engages every day in contemplation sessions of her body and her vagina in front of a mirror. In a country where women are not allowed to show their faces, Marie questions herself with the purest innocence in the world:

"Hadn't her sister-in-law reported to her that, from what she had heard, women vagina, just like their faces, were very different from each other? ... Mary was certain that hers was beautiful, and, if it was, why one should be deprived of looking at it? ... " $\left(^{72}\right)$

71) Le firman aveugle, Fayard, Paris, 1993, p. 107-108

72) Ibid., p. 87 
Kadare tackles again the taboo of virginity and the "myth" of the trousseau that young girls had to prepare throughout their youth to take it with them on their wedding day:

"Having paced the room for a moment, she had stopped to contemplate the street through which her fiancé was supposed to arrive, then her gaze had ended up resting on the chest containing her trousseau. There, among dozens of clothes, sheets, embroideries accumulated over the years, were a dozen women's silk underwear as light as glass smoke ... My God, how had she not thought of giving him this surprise earlier?...

She slowly approached the cabinet ... So there they were, virginal and frozen ... No, she was going to try on these diaphanous clothes one after the other, she would baptize them, sanctify them, she would try them on. would imbue with the heat, the aroma, the stains, the sap, and the groans of love. " $\left({ }^{73}\right)$

Sometimes, the description of the feminine toilet insists less on this fourth dimension of the woman than on the masculine glance carried on this one. This is the case with the description of Marguerite's toilet in Chronicle of the Stone Town:

"The room was empty.

Where could Marguerite be? On the blanket serving as a bedspread were placed a few pieces of folded fine linen. I heard a gurgling sound then and guessed that she was in the bathroom.

I waited a long time. Finally, she came back from the bathroom and appeared to me wrapped in a large bathrobe, her hair down, still wet. She walked over to the mirror, took her comb, and began to comb her hair. While combing herself, she sang in a low voice:

Over there in Holland;

In the land of windmills.

Then she grabbed her compact from the table, opened her robe, and began to do something with a tassel.

The moment, stripping herself off, she bent down to pick up her laundry from the bed, I closed my eyes. When I reopened them, the laces on her body gave me the effect of white butterflies as if placed in a circle on her chest, her hips, the top of her thighs, those white

73) Le firman aveugle Op. cit. , p. 85-86 
butterflies of the fields that appear in spring and that I had often pursued without ever succeeding in catching one. $"\left({ }^{74}\right)$

The real mirror here is not the one in front of Marguerite, but the gaze of little Kadaré hidden above the ceiling of her bedroom. The entire description is also marked by the presence of this look. But, although this gaze is fixed on Marguerite, more than about her, it tells us about little Kadaré.

In the case of Silva, in The Concert, this masculine gaze, which this time is that of Gjergj, her husband, appears in an internalized form:

"As she manipulated the shower handle, she was aware that at the same time, in their room where he was waiting for her, Gjergj imagined the water depositing its foam on her skin." $\left({ }^{75}\right)$

Other times, this fourth dimension turns into a process, a staging tool, as in this passage we took from Broken April:

"While combing herself in front of the mirror, Diane, out of the corner of her eye, observed the flakes of smoke on Bessian's pensive face. The comb slid more slowly through her hair. With a lazy gesture, she put it on the dresser, gently she walked lightly towards the window, her eyes still fixed on her husband in the mirror, as if she had wanted to escape his attention. " $\left({ }^{76}\right)$

Here, more than to Diane, the mirror serves to Kadaré himself to control the scene. Using a cinematographic process, he succeeds thanks to the presence of this mirror in finding the ideal location for his "camera". In this way, although she remains fixed, the two figures are simultaneously in their field of vision, and at the same time, the reader can notice that Diane is observing Bessian in secret and that she seems to seek to avoid him. In an extremely subtle way, Kadaré thus marks the beginning of Diane's detachment from her husband's world, which constitutes one of the main axes of the novel. Such a process perfectly renders the distant silence behind which Diane will take refuge more and more until she becomes a stranger to Bessian.

The mode of narration constitutes one of the essential elements in the variety of the "game of mirrors" that we have just seen. Indeed, in the passages quoted above, we find all types of

\footnotetext{
74) Kronikë në gur, op. cit. , p. 81-82

75) Koncert në fund të stinës, op. cit. , p. 450

76) Avril brisé, op. cit. , p. 143
} 
narration. To describe the "fourth dimension", of Daisy, in Dossier H., of Mary, in The hijab's caravan, of Mira, in The Great Winter, and of Silva, in The Concert, Kadaré positions himself as an external and omniscient narrator, his privileged position.

On the other hand, for the description of the queen in The Black Year, he disguises himself as an inner narrator.

Sometimes, as is the case with Teuta's description in November of a capital city, Kadaré instead prefers the position of an observer and external narrator.

Other times, as in the description of the first hot shower taken by Katrina and her mountain friends, there is a more complex phenomenon. The we that Kadare uses in this description unite in one voice the simultaneous accounts of two narrators: the first is an inner narrator and, the second, an omniscient witness narrator. The first lets us know what's going on deep inside Katrina, and the second lets us see that the other girls must be thinking and feeling the same as her, which adds to the emotional reach of this scene and makes it a so striking and symbolic event for these young girls as well as for the reader.

Such complexity is also manifested, albeit in a different way, in Marguerite's description in Chronicle of the Stone Town. This time, the inner narrator that is the little Kadare becomes concerning Marguerite an observer and witness narrator. The distance and the purely descriptive character, specific to this type of narration, convey perfectly the daze and incomprehension that dominate in the gaze of little Kadare faced with the nudity of the body and the intimacy of female gestures, unknown to him until that precise moment.

Why so much insistence from Kadaré on this fourth dimension? Mainly for three reasons in our opinion.

The first reason is revealed to us by Kadaré himself when he makes Diane say, in Broken April:

"In the end, the first condition for a woman to be compared to a nymph is that she has a salle de bain *, right? " $\left({ }^{77}\right)$

Kadaré thereby tries to legitimize self-care and the desire to please in a society where these two important aspects of a woman's life fell under the popular saying: "The village burns and the bitch continues to comb her hair", especially in the context of the communist regime

\footnotetext{
$*_{\text {in french in the text. }}$

77) Avril brisé, op. cit. , p. 101
} 
where the "village" was continually "on fire", because that "fortress of Marxism-Leninism", the regime wanted to make of Albania, was "at all times threatened by the aggression and blockade of capitalist and revisionist countries".

By the description of this woman's fourth dimension, Kadare wants at the same time to emphasize the presence of the woman's body and its carnal reality. Indeed, the toilet constitutes a situation favorable to the representation of the nudity of this body.

It is also to Kadare that we owe the first nudes of women in Albanian literature published under communism. He thus broke another taboo of "traditional puritanism".

The last reason is due to this unstoppable desire in Kadare to reveal feminine intimacy, a desire which seems governed by a latent sensuality and eroticism, or rather forced to remain hidden. Failing to express itself openly, this eroticism is channeled and released through the long descriptions that Kadaré devotes to the ladies' toilette.

\section{Conclusion}

As for Kadare himself, who knew literature before, long before knowing freedom and that it is precisely literature that led him to freedom, and not the other way around, Albanian women lived their first emancipation through the literature of Kadare and his female characters long before it became an achievable part of their daily reality. A whole gallery of female characters, although often episodic, as well as a wide variety of narration methods have come together to convey the Kadarean ideal of the emancipation of women, an emancipation claimed not in the name of an ideology, but in the name of life, of the thirst for life. This ideal of feminine life, animated by love and dignity, by its aspiration for freedom, for the full blossoming of her sexuality and intimacy, not only refuses the models of the "new woman" of communism going far beyond them but takes shape and presents itself as their perfect antimodel which springs to life, moves and evolves in a parallel world and imaginary modernity.

\section{References}

[1] BEGEJA, KSANTHIPI, La famille en RPS d'Albanie, 8 Nëntori, Tirana, 1984

[2] CHAPONIERE, CORINNE, Le mystère féminin, 1994

[3] FAYE, ERIC, Ismail Kadaré, Prométhée porte-feu, José Corti, Paris, 1991 
[4] FLAUBERT, quoted by Edouard MAYNIAL in the preface of Mme Bovary, Garnier Frères, 1961

[5] HOXHA, ENVER, Le socialisme en Albanie, Union Générale des éditeurs, Paris, 1974

[6] KADARE, ISMAIL, Avril brisé, Fayard, Paris, 1982

[7] KADARE, ISMAIL, Clair de Lune, Fayard, Paris, 1993

[8] KADARE, ISMAIL, Dasma, Naim Frashëri, Tiranë, 1968

[9] KADARE, ISMAIL, Dimri i Madh, Naim Frashëri, Tiranë, 1983

[10] KADARE, ISMAIL, firman aveugle, Fayard, Paris, 1993

[11] KADARE, ISMAIL, Ftesë në Studio, Naim Frashëri, Tiranë, 1990

[12] KADARE, ISMAIL, Ftesë në Studio, Naim Frashëri, Tiranë, 1990

[13] KADARE, ISMAIL, Koncert në fund të stinës, Onufri, Tiranë, 2008

[14] KADARE, ISMAIL, Kronikë në gur,Naim Frashëri, 1981

[15] KADARE, ISMAIL, L'Année noire, Fayard, Paris, 1987

[16] KADARE, ISMAIL, Le dossier H, Folio, Gallimard, Paris, 1990

[17] KADARE, ISMAIL, Le Monstre, Fayard, Paris, 1991

[18] KADARE, ISMAIL, Le Poids de la croix, Fayard, Paris, 1991

[19] KADARE, ISMAIL, Le Poids de la croix, Fayard, Paris, 1991

[20] KADARE, ISMAIL, Nëntori i një kryeqyteti "Naim Frashëri", Tiranë, 1983

[21] KADARE, ISMAIL, Printemps albanais, Fayard, Paris, 1991

[22] MITCHELL, ANNE-MARIE. Un Rhapsode Albanais : Ismail Kadaré, Le Temps parallèle, Marseille, 1990

[23] VANEIGEM, RAOUL, Le livre des plaisirs, Ancre, 1979 